papers on the origin of species, we observe the adaptive action and reaction of the heredity germ over long periods of time. We also observe the secular action of natural selection (Darwin's selection factor), the secular direct reaction to environment (Buffon's factor), the secular adaptive action of habit (Lamarck's factor), the secular adaptive reaction to the living environment (Darwin's factor). We sharply separate Darwin's factor of selection, which has no energy content, from the above four energetic forces of evolution, namely, heredity, physical environment, living environment, and individual development or ontogeny. This is the principle of tetraplasy and tetrakinesis.

This momentary lapse into speculative as distinguished from purely observational consideration of the problem of the origin of species may clarify the transition from zoology to palæontology.

In palæontology an entirely new series of principles is discovered in speciation which are quite beyond the eye of the zoologist. Chief among thesenew principles is that dimly perceived by Darwin in the words 'analogous variation'; it is that of germinal or evolutionary trend in a definite direction, the 'mutations richtung' of Neumayr. Out of this springs Osborn's principle of rectigradation observed in the rise of adaptive characters from the germ-plasm, that is, new specific characters which pass continuously from the most rudimentary and inefficient into the most efficient and highly developed stages. It may be a matter of interest to members of the British Association to recall that this principle was presented to the Association in 1889 by the present speaker. Through unbroken observation during the intervening thirty-seven years this rectigradation principle has been confirmed in four great orders of hoofed mammals, namely, the horses, the rhinoceroses, the titanotheres, and the proboscideans. Research on the two latter groups fills two great monographs aggregating nearly a million words and covering, in the case of the Proboscidea, the analysis of the mode of origin of more than 350 species and, in the case of the titanotheres, the chief stages of specific development extending from Lower Eocene through Lower Oligocene time, when these animals suddenly disappear.

An epitome of these observations is presented in three diagrams in which the three outstanding principles discovered in palæontology are observed: First, the unbroken continuity of speciation, which becomes absolute as the gaps are filled by discovery. Second, the constitutional predisposition to speciate in certain predetermined directions which must be inherent in the germ-plasm of ancestral forms. Third, that these constitutional predispositions are not released except through adaptive reaction to new conditions of life; they are not, therefore, of the nature of inherent perfecting tendency, but, rather, of the nature of a potentiality to appear when the need for them arises. For example; the rhinoceroses have the potentiality of developing two horns, an anterior horn on the nasal bone and a posterior horn on the frontal bone. But in the fourteen branches into which this great subfamily subdivides in its migrations to all parts of the earth, this double potentiality is seldom availed of, sometimes not availed of at all.

\section{Conclusions.}

We seem to have reached an entirely new era in research on the problem of the origin of species, marked by the decline and death of speculations and theories advanced upon the very limited knowledge of the first half of the nineteenth century. Through zoology and palæontology we have reached a solution of the least difficult half of the problem with which Charles Darwin was confronted: we know the modes by which subspecies and species originate; in fact, there is little more on this point to be known. But this very knowledge renders the problem of causes infinitely more difficult than it appeared to Darwin. The causes of 'variation,' to use the term he employed for the evolutionary process, lie in the way before us. They may be resolved or they may prove to be beyond human solution. We must resolutely face these alternatives, and in the meantime continue our synthesis over every field of biologic research.

\title{
The Geographical Distribution of Magnetic Observatories.
}

\section{By Dr. C. Chree, F.R.S.}

$\mathrm{T}$ HE provision for observational work in terrestrial magnetism is different in kind in different countries, and in some countries-Great Britain, for example-- the provision made is of more than one kind. The object in view may be purely utilitarian, or purely scientific, or partly both. Originally the provision of information necessary for the use of the compass was the one utilitarian object generally recognised. To secure this object to the best advantage, the natural course is to make a single department responsible for the running of magnetic observatories, the taking of field observations and the preparation of charts. Thus, in the United States the Coast and Geodetic Survey controls the whole of official terrestrial magnetism. The number and position of the observatories-Sitka, Cheltenham, Tucson, Vieques (Porto Rico), and Honolulu-is determined primarily by survey considerations. The same idea prevailed to a certain extent in India, but the oldest magnetic observatory, Alibag-regarded as the continuation of Colaba, Bombay-represents a more usual form of development.

In most countries terrestrial magnetism has not been an independent plant, but from the point of view of astronomers and meteorologists has been a parasitical growth on astronomy or meteorology. Greenwich may perhaps be regarded as an example of this. At present most magnetic observatories are under the meteorological service of the country, and one of the two international associations concerned with the subject is the Magnetic Commission of the International Meteorological Committee. It is under its auspices that a selection of international quiet and disturbed days is made at De Bilt, Netherlands. The other international association, the Section of Terrestrial Magnetism and Electricity of the International

NO. 2964, vOL. I I 8] 
Union of Geodesy and Geophysics, represents the more distinctly scientific aspects of the subject. Its existence distinct from the Section of Meteorology is largely due to the independent position assigned to terrestrial magnetism in the United States and some other countries.

In-France-as is still the case in Germany, Denmark, Holland, Belgium, and Portugal-terrestrial magnetism used to be in the main a branch of meteorology, but it now comes under the Institute of Geophysics, presided over by Prof. Maurain, of Paris. In Italy there was once an observatory at Rome under the Meteorological Office. But Rome-like Kew of later yearssuffered from artificial disturbance and had to be given up, and Italy remained for many years without a continuously recording magnetic observatory. It succeeded after the War to the observatory maintained at Pola by the Austrian Admiralty, which is now controlled by the Italian Hydrographic Office.

Of the observatories independent of State control, the most important are those of the Jesuit Order and of the Carnegie Institution of Washington. The former group includes Stonyhurst - one of the oldest magnetic observatories now existing-Ebro (Tortosa) and Lukiapang (successor to Zi-ka-wei) in China. The Carnegie observatories at Watheroo (Western Australia) and Huancayo (Peru) are of recent creation.

In Bulletin, No. 5, r924, of the International Section of Terrestrial Magnetism and Electricity, 66 magnetic observatories are included in the list on pp. 146-148, but some of these had not been active for some years, and a few, for example Kew, are now extinct. The number may seem large, but it means only one observatory per three million square miles of the earth's surface, while the diversity in the phenomena to be recorded is very great. Further, the distribution is very irregular. Of the 66 observatories mentioned above some 30 were in Europe, and only ${ }_{1} 3$ were in the southern hemisphere. Only three were north of $60^{\circ} \mathrm{N}$., and only two were south of $40^{\circ} \mathrm{S}$. The regions of the globe in which observatories are particularly scarce call for our special consideration.

Until a few years ago Pavlovsk $\left(59^{\circ} 4 \mathrm{r}^{\prime} \mathrm{N}\right.$.) was the most northerly regular station provided with magnetographs. No publications from it or other Russian observatories for years after the commencement of the War were available until comparatively recently. But it would seem that unbroken records were obtained at Pavlovsk and Kasan in Russia, and at Ekaterinburg in Siberia. Records were also obtained at Irkutsk, or at Zuya in its neighbourhood, down to 1920. The Russians have also established a new station at Matochkin Shar $\left(73^{\circ} 15^{\prime} \mathrm{N}\right.$.), in Nova Zembla, a neighbourhood where Prof. Birkeland had a temporary station in 1902-3. This is the most northerly station on the international list. From information recently supplied we learn that it is equipped with Eschenhagen magnetographs recording $\mathrm{D}, \mathrm{H}$, and $\mathrm{V}$ (declination, horizontal force and vertical force), the sensitivenèss of these instruments being respectively $\mathrm{I}^{\prime} \cdot 0,22.6 \gamma$ and $5.7 \gamma$ per $\mathrm{mm}$. More suitable values for a station where $\mathrm{H}$ is very low and disturbance large, would be $2^{\prime}$ or $3^{\prime}$ per $\mathrm{mm}$. for D, and $10 \gamma$ for $\mathrm{H}$ and $\mathrm{V}$. The magnetograph room itself seems to be of wood, but the instruments stand on a concrete and brick foundation. This foundation should be satisfactory if it is non-magnetic, a property, however, which is rather unusual in brick. Further, Russian observatories seem also in contemplation at Taschkent and in Eastern Siberia, a part of the world unrepresented at present.

Of the two other observatories on the international list north of $60^{\circ} \mathrm{N}$., one, Sodankylä $\left(67^{\circ} 22^{\prime} \mathrm{N}\right.$.), is run by the Finnish Government, which of late years has also been active in survey work. The third of the new high latitude stations, Lerwick $\left(60^{\circ} 9^{\prime} \mathrm{N}\right.$.), in the Shetland Islands, was instituted by the Meteorological Office, and magnetographs were in operation in 1923 . Another high latitude station of comparatively recent origin calling for notice is Meanook $\left(54^{\circ} 37^{\prime} \mathrm{N}\right.$.) in Canada. This was only partially equipped in $\mathrm{r}^{2} \mathrm{24}$, and one of the resolutions passed by the Section of Terrestrial Magnetism and Electricity at its meeting in that year at Madrid emphasised the importance of full equipment. Meanook is one of the nearest stations to the north magnetic pole. Yet another high latitude observatory is being instituted by the Danish Government at Godhavn $\left(69^{\circ} \times 5^{\prime}\right.$ N., $53^{\circ} 14^{\prime}$ W.) in western Greenland. Pavilions for absolute observations and for magnetographs connected by a corridor form a single building. An important feature is that the equipment includes two complete sets of magnetographs, one of low sensitiveness, so as to make provision for large disturbances.

Observatories in high magnetic latitudes (that is, latitudes where dip is high) have special difficulties to contend with. Magnetic disturbance is large, and $\mathrm{H}$ being small, changes in $\mathrm{D}$ are enormous, rendering ordinary $\mathrm{D}$ magnetographs unsuitable. On the other hand, small changes of dip represent such large changes of $\mathrm{V}$ that ordinary dip instruments are unequal to the satisfactory determination of base line values for $\mathrm{V}$ curves. It is thus a matter of general interest that the National Physical Laboratory has under construction an instrument for measuring $\mathrm{V}$ directly. The desirability of such an instrument was also the subject of a resolution at Madrid. High latitude stations are of special importance, not merely because they record magnetic disturbances in the regions where these are most developed, but also on account of the light they may throw on the relation between magnetic and auroral phenomena. The importance of this relation has been increased by the development of radio, and the evidence that has recently been obtained as to the influence on radio of a 'conducting layer' at about the height which Prof. Störmer has found for the lower level of aurora. So far at least as latitude is concerned, Lerwick should be favourably situated for combined observations on terrestrial magnetism and aurora. But the full utilisation of the opportunities presented by such a station calls not merely for special knowledge and equipment, but also for an ample and vigorous staff, as a lot of night work is involved under probably severe climatic conditions.

Another region where magnetic observatories have hitherto been sparse includes the geographical equator. The international list contains no station between Buitenzorg (Batavia, $6^{\circ} \mathrm{II}^{\prime} \mathrm{S}$.) and Kodaikanal $\left(10^{\circ} 14^{\prime} \mathrm{N}\right.$.), and a footnote supplies the regrettable information that Kodaikanal stopped recording in 
1923. This will leave more than $20^{\circ}$ of latitude unrepresented between Batavia and Antipolo ( $14^{\circ} 36^{\prime}$ N.). Kodaikanal was one of the stations supported by the Indian Survey, which has also closed down observatories at Barrackpore $\left(22^{\circ} 46^{\prime} \mathrm{N}\right.$.) and Toungoo ( $18^{\circ}$ $56^{\prime} \mathrm{N}$.), thus leaving only two magnetic observatories, Alibag and Dehra Dun, in the whole Indian empire. The fact that, as compared with pre-War times, magnetic observatories have fared worse in India than in Russia seems to afford food for reflection. If Kodaikanal is an unsuitable site, as is rather suggested by remarks in some of the Indian Survey publications, the resuscitation of Trivandrum, memorable for the work of $\mathrm{J}$. A. Broun, would provide a station nearer to the equator than any existing observatory in the northern hemisphere.

Other areas within the British Empire where magnetism is somewhat poorly represented are South Africa and Australia. There was once a magnetic observatory at Cape Town, and a new observatory somewhere else in South Africa has been talked about, but at present the Royal Alfred Observatory in Mauritius seems to be the only one in that part of the world. Melbourne was once the site of a magnetic observatory, but has long been unsuitable for that purpose. Recently an observatory has been set agoing at Toolangi in Victoria, but that seems the only observatory in Australia, with the exception of Watheroo, which belongs to the Carnegie Institution of Washington.

New Zealand has a magnetic observatory at Christchurch, and with assistance from the Admiralty and the Carnegie Institution is also maintaining what was originally a German observatory at Apia, Samoa. It is scarcely necessary to say, in view of the scarcity of magnetic observatories in or near the Pacific Ocean, that the stoppage of Apia observatory would have been a great misfortune.

The latest observatory of the Carnegie Institution, Huancayo $\left(12^{\circ} 3^{\prime} \mathrm{S}\right.$.), is in a way unique from its proximity to the magnetic equator. Dip there at present is less than $\mathrm{r}^{\circ}$, and its measurement must present unusual features. Huancayo is situated, moreover, in a continent, South America, where additional magnetic observatories are badly wanted.

\section{Obituary.}

\section{Sir William Ridgeway.}

WILLIAM RIDGEWAY, a son of the Rev. J. H. Ridgeway, of Ballydermot, King's County, was born in $\mathrm{x}_{53}$; he had a brilliant career in Trinity College, Dublin, and later at Gonville and Caius College, Cambridge, graduating as fifth Classic in 1880 , and was elected a fellow of his College. In r883 he was appointed to the chair of Greek in Queen's College, Cork, and while holding that appointment he resided for five months each year in Cambridge. In 1892 he was elected to the Disney professorship of archæology in Cambridge, and shortly afterwards resigned his chair at Cork. He was re-elected a fellow of his College, and had also been Brereton reader in classics since 1907 . He was Gifford lecturer in natural religion, University of Aberdeen, in I909-II ; Stokes lecturer in Irish archæology, Dublin, I9o9; and Hermione lecturer in art, Dublin, rgrr. He was president of the Royal Anthropological Institute, 1908-10; of the Anthropological Section of the British Association, I908; and had been president of the Cambridge Philological, Antiquarian, Classical and Anthropological Societies. He was elected a fellow of the British Academy in 1904, and was a foreign member of various learned societies in Europe. His learning was recognised by other universities, and he had conferred on him Hon. D.Litt. Dublin, r9o2; Hon. D.Litt. Manchester, r9o6; Hon. LL.D. Aberdeen, 1908 ; and gained the Sc.D. of Cambridge for his work on the horse. He was knighted in rgrg. He wrote numerous contributions to classical, philological, anthropological, zoological and other journals, and the following books : "Origin of Metallic Currency and Weight Standards," I892 ; "The Early Age of Greece," I90I; "The Origin and Influence of the Thoroughbred Horse," r905 ; "The Origin of Tragedy," r9ro.

This bare enumeration of the academic distinctions and of the writings of Sir William Ridgeway will serve to show the wide extent of his erudition and the great range of his interests. These were constantly exhibited when he joined in discussions at classical and scientific societies, in which he usually gave a free rein to his sense of humour, and also to caustic criticism. His strong personality and the definite views he expressed vividly in speech and writing, combined with his love of controversy, sometimes strained the forbearance of many friends, even occasionally to the breaking point. He was a man of pronounced likes and dislikes, and it was often a moot point whether he was not as dangerous to the causes he espoused and to his friends as to his enemies, for he was liable through friendly enthusiasm to overstate the case at issue. He entered wholeheartedly into a fray, whether it was Irish education, the Irish and English Anglican Church, or University politics, as those can testify who remember the discussions on the degrees for women and on compulsory Greek in the University of Cambridge.

Sir William was emphatically a driving force in the University, and spared no pains in furthering the wellbeing of the institutions to which he belonged, to take but two examples: the Cambridge Antiquarian Society and the Museum of Archæology and Ethnology. It was due to his energy that a lectureship in ethnology was instituted, and again largely to him that nine years later it was converted into a readership; in this and other ways he was instrumental in founding the Cambridge School of Anthropology. He very early recognised the value of ethnology in elucidating obscure points in classics and archæology; in some respects he was a pioneer in these comparative studies, and he delighted to recall how his heterodox views later gained acceptance from more conservative scholars.

Sir William stimulated very many students, naturally mainly in classical archæology, of whom a considerable proportion have gained great eminence, and he was careful to keep in frequent correspondence with them ; but he also had a large number of correspondents throughout the world on an amazing variety of

NO. 2964, VOL. I I 8 ] 